\title{
Evaluation of the Financial Feasibility of Restoration and Reusing the Sugar Industrial Heritage Site - A Comparison among BOT, ROT and OT Concession Frameworks
}

\author{
Lee Duu-Hwa, Lin Ching-Ching, Lin Hui-Wen, and Hsu Min-Fu
}

\begin{abstract}
This study utilizes engineering economics/cost-benefit analysis with comprehensive cost and revenue estimations to evaluate the short-term and medium-term financial feasibility analysis of restoration and reuse of the Sugar Railway Park Industrial Heritage Site in Taiwan, and also compares different entrusted operation and management such as combination of BOT, ROT and OT and solely OT concession frameworks. Results reveal that the Park's short-term and medium-term NPV of combination of BOT/ROT/OT framework is USD 7.24 million and USD 43.99 million, SLR is $463.81 \%$ and $1800.65 \%$, project ERR is $16.05 \%$ and $15.45 \%$ at an interest rate of $3.5 \%$, which implies that it can fully cover its own expenses, make profit, which indicates the attraction of this investment to the Sugar Company. Results also describe that the project is financial infeasible when adopting solely OT concession method. The financial performance of the Park is sensitive to discount rate. The Park not only generates economic value, conserves precious cultural and industrial heritage of past sugar cane cultivation history in Tainan, and provides value of experience tourism for visitors, long-term care, healthy life, promotes concepts of the circular economy which are the comprehensive social value of local and global people at the historical city in Taiwan.
\end{abstract}

Index Terms-Sugar railway, industrial heritage conservation, cultural creative park, restoration and reuse, circular economy.

\section{INTRODUCTION}

The cane sugar was a major export product from Dutch colonization in 17 century to around 1964 in Taiwan [1], and grew extensively during Japanese colonial period during 1895 to 1945 [2]. The first modern sugar manufacturing factory was founded in Kio-A-Thau district at Kaohsiung City in 1902 [2], and now a cultural heritage and operating as a Taiwan Sugar Museum for purposes of sugar culture conservation and developing experience tourism. Because the sugar cane was one of the most valuable cash crop, the large area of land used to cultivate sugar cane before. After rapid development of economic growth of Taiwan in the 1970s,

Manuscript received December 30, 2017; revised May 1, 2018.This work was supported in part by both the Ministry of Science and Technology under Grant 105-2410-H-006-065, and Taiwan Sugar Corporation (TSC) with commissioned research project, Investigation Survey Project on Reuse, Management and Marketing of Hsin-Ying Sugar Factory.

Lee Duu-Hwa and Lin Ching-Ching are with the Institute of Applied Economics, National Taiwan Ocean University, Taiwan (e-mail: dhlee@mail.ntou.edu.tw. sunny125964@gmail.com).

Lin Hui-Wen is with the Institute of Creative Industries Design, National Cheng Kung University, Taiwan (e-mail: hwlin@mail.ncku.edu.tw).

Hsu Min-Fu is with the Department of Architecture, National Cheng Kung University, Taiwan (e-mail:z7510004@email.ncku.edu.tw). only few sugar factory still produce sugar and turn to import sugar to fulfill domestic demand in recent years [1]. Under sustainable operating pressure, the large area of idle land held by the former monopoly sugar company needs to be activated to generate continuously cash inflow to keep stable operating of the company.

The establishment of a creative site from a former industrial area has become a trend across the world [2]. Many industry heritages such as sugar [2], tobacco, wine, plastic [3] heritage are transforming to the creative park to support creative industry and tourism to increase the innovation power and income of the local community.

The sugar railway is an early network of sugar plants for transporting sugar cane and workers between sugarcane fields and sugar factory which comprise several lines and achieved 2964.6 kilometers of sugar railways across Taiwan [1]. The sugar railway is the highlight of sugar industry heritage for tourists to take the sugar railway tour by old sugar carriage to experience past sugar cane culture in Taiwan in recent years. The research sugar factory in this study is one of three major factories which has workable sugar railway lines and reformed a Sugar Railway Park for experience tourism, sightseeing, having delicious ice lolly and taking photos by tourists which located in the historical city, Tainan. The existed Sugar Railway Park only occupied northern part of entire sugar factory, and now it starts to transform into a new multifunctional park through inscription old architectures in Japanese ruled period as cultural heritage, and also activate idle land used for circular economy industry, long-term care center, health and athlete facilities, LOHAS (Lifestyles of Health and Sustainability) accommodation area, even Cinema and TV Park and anime park.

As [3] states, many unique historical buildings have been restored and reused in Taiwan and provided multiple social values to conform to the cultural heritage and historical conservation trend. With a rapidly increasing amount of cultural heritage restoration and reuse budget pressure, the public and private sectors try to find a balance between private participation and public value for long-lasting maintenance and conservation of cultural heritage. Financial performance is one of the important key factors in the continuous conservation of cultural heritage. This study adopts financial analysis method which is named engineering economy/cost-benefit analysis to reveal the financial feasibility of a transforming sugar factory to a Sugar Railway Dynamic Reservation Creative Park in Tainan, a historical city in Taiwan.

Private participation in infrastructure (PPI) is an effective 
method to decrease financial burden and risk of investment on infrastructure by governments and take advantage of operating efficiency of private enterprise which was originated from the public-private partnership (PPP) in infrastructure [4]. There are four levels of private sector participation from public owns and private ownership by management and operating contracts, leases/afterimage, concessions and BOT-types projects, and joint venture/partial divestiture of public assets [5].

In Taiwan, BOT(build-operate-transfer)-types of PPP are popular PPI policy to induce private sectors to participate in constructing infrastructure and facility with social value such as Taiwan High Speed Railway BOT project which is one of the largest BOT project with USD 18 billion investment cost in the world at year 1996, and also popular for refurbishment and restoration of cultural heritage sites such as Songshan Cultural and Creative Park which is a former tobacco factory was initially constructed in 1937 to manufacture tobacco under the Japanese government.

The funding sources of restoration cost of heritage may come from public or private sectors. This study considers adequate PPP process combination such as balanced combination of BOT (implies all initial costs funding by private sectors including construction cost of new buildings), ROT (refurbish-operate-transfer)(implies initial costs of BOT excluding new building construction) and OT (operate-transfer)(implies initial cost comes from public sectors) which can decrease the financing obstacles for central government and the state-owned sugar company, and encourage involvement of private sectors. Solely OT frameworks can evaluate the financial feasibility of refurbishment of Sugar Railway Park funding by public sector itself. This study surveys costs of BOT, ROT and OT from the sugar company and estimates revenues calculate the financial performance of the project, and to compare the results between two kinds of PPP frameworks to provide suggestions for the project and similar cultural heritage projects in the future.

Engineering economics (or cost-benefit analysis) is a financial feasibility process which is adequate in investment projects to determine their financial efficiency using the procedures of compound/discount interest while considering the time value of money under the principle of economic equivalence. The analysis of the financial feasibility of a heritage restoration project was used in rapid development in the interdisciplinary convergence of cultural economic evaluation, cultural heritage conservation, and construction.

Reference [6] launched The Copan Valley Project which is one of famous UNESCO World Heritage for the famous site of Maya to support sustainable economic growth through tourism in one of the poorest regions of Honduras. The cost of the project is USD 13.4 million from 2003 to 2009, the NPV of the medium-growth scenario was USD 9.4 million and ERR was $20.5 \%$ which implies the project is financially feasible and sustainable tourism could be a good activity for cultural heritage and local people.

Reference [7] found that inscription on the World Heritage List can increase the local agriculture production, tourism income and generate employment, the case of Mount Lofty Ranges in Australia will generate a NPV of USD 149 million and benefit/cost ratio at 2.6 in medium growth scenario.

Reference [8] evaluated a large indoor retail market named Hala Koszyki which is constructed in the commercial district in the center of Warsaw in 1908 and conducted an engineering economics analysis of the restoration and reuse of this retail market. Results showed that the rate of return for the project was $16 \%$ (the NPV was 12 million euros), whereas the rate of return was $19 \%$ (including constructing the new buildings). This indicated that the return of a project of restoration and reuse of old architecture with constructing new buildings (and new business behaviors) can generate more revenue higher than that in only restoration projects, just like the case in this study. Hala Koszyki officially re-opened in October 2016.

Reference [9] performed a project to refurbish a large warehouse at the rear of Bishop Street to accommodate for archives for additional 300,000 boxes of archives. The cost of the Warehouse Development Plan (WDP) is estimated at 17.7 million euros in eight years. The project will generate NPV of 4.5 million euros, IRR of $6.8 \%$ and benefit-cost ratio of 1.38 at discount rate of 5\% from 2015 to 2021 which reveal the project is financially feasible.

Reference [10] using PERT probability distribution and a simulation model of Morimoto and Hope (2001) to estimate the probability distribution of NPV, and found that 95th percentile of the cumulative NPV is positive but 5th percentile is negative which confirm the benefit of the Three Gorges Project. The 5th percentile, mean, and the 95th percentile of the cumulative NPV with a 5\% discount rate are about $-114,424$, and 1321 billion RMB respectively.

Reference [11] adopted cost-benefit analysis and contingent valuation to estimate the restoration value and visitor value of heritage of the city of Valdivia in Chile and revealed the restoration value of the project will be 145,615 euros under 15000 tourists with a 5,000 pesos entrance price at $7 \%$ discount rate. But under some cases such as 10,000 tourists with 5,000 pesos entrance price at $10 \%$ discount rate would generate $-57,632$ euros loss. Reference [12-14] were adopted the same method to evaluate the economic value of cultural heritage. These studies revealed that engineering economics/cost-benefit analysis is adequate to current cultural heritage evaluation and can provide valuable references for decision makers to decide restoration and reuse policies.

This study adopts engineering economics/cost-benefit to evaluate the short-term and median-term financial feasibility of the extensive development of Sugar Railway Dynamic Reservation Park Heritage Project and compares effects of combination of BOT, ROT and OT and solely OT frameworks, and performs risk analyses to assist decision-makers of the government and the sugar railway park in their decisions and to provide criteria for future cultural heritage reuse projects.

\section{THE MODEL}

\section{A. Model Introduction}

Engineering economics is a useful method for decision-making regarding invest in cultural heritage restoration and reuse projects [3]. According to [15], the 
initial publication of The Engineering Economist by Arthur Lesser in 1955 confirmed engineering economics as an academic discipline.

Engineering economics considers lifetime financial planning for future construction and operations during engineering projects for heritage restoration and reuse based on an economic theory such as time value of money, economic equivalence, opportunity cost and real purchasing power. The financial analysis and risk sensitivity analysis of restoration and reuse projects under different possible discount rates, times, and risks can provide financial indicators for decision-making in cultural heritage restoration and reuse.

\section{B. Financial Indicators}

The following nine financial criteria were considered as mentioned above [16].

1) Net Present Value (NPV)

The NPV serves as a reference when making investment-related decisions. An investment project can be accepted if cash inflows are greater than cash outflows, i.e. NPV $>0$, and rejected otherwise.

2) Self-Liquidating Ratio (SLR)

An SLR greater than $100 \%$ indicates that a project is entirely self-liquidating, that is, all invested construction costs can be returned as net operating income. An SLR less than $100 \%$ but greater than $0 \%$ indicates that a project is not entirely self-liquidating and requires government investment in infrastructure.

Benefit-Cost Ratio ( $\mathrm{B} / \mathrm{C}$ ratio)

3) The Benefit-Cost $(B / C)$ ratio is calculated by dividing present value of revenue by present value of costs. A B/C ratio greater than 1 indicates the financial feasibility of the project.

4) Internal Rate of Return (IRR)

The IRR makes the estimated total current value of cash inflows in an investment plan equal to the estimated current total value of cash outflows; that is, it allows the project to break-even and NPV to equal 0.

5) External Rate of Return (ERR)

In case of high cash flow volatility in an investment project, the IRR can produce multiple solutions which may cause indecision in policy-makers. In this case, adjusting the IRR to the WACC (weighted average capital cost) and determining the current value of cash outflows over the term of the investment using the discounted WACC, cash inflows compounded by the WACC, and making cash inflow and outflow discount rates equal is the ERR.

If the weighted cost of capital is smaller than ERR, then NPV $>0$ and the project should be accepted.

6) Discount Payback Period (DPP)

A short payback period after the discount attracts investors.

7) Profit Index (PI)

After the discount, investments starting from NT\$1 can earn future operating income.

A project is feasible if $\mathrm{PI}>1$ and not feasible otherwise.

8) Equity Rate of Return (Equity IRR)

IRR that can only be obtained from equity capital. Higher
Equity IRR is more beneficial for shareholders.

9) Equity Net Present Value (Equity ERR)

NPV that can be obtained only from equity capital. Higher Equity ERR is more beneficial for shareholders. This study used the nine indicators described above to determine financial indicators and conducted risk analysis by integrating changes in site revenues and costs.

\section{PPP frameworks}

The Sugar Plant evaluation in this study adopts two concession frameworks including a combination of BOT, ROT, OT and solely OT. These concession modes try to find a balance point of rights or obligations of investment projects for construction of infrastructure between public and private sectors. BOT implies public sectors delegate private sectors to build new facilities and operate for a period of time, then transfer back to public sectors at the end of the contract. All initial costs are paid by private implies higher risk burden and less profit or private sectors which may decrease willing to participate in the project, and BOT is beneficial to the government. ROT implies private sectors refurbishes and reconstructs old or used facilities, and do not construct new facilities like BOT which increase economic incentive to induce more private sectors to take part in the project than BOT. OT implies government invest in all infrastructures and facilities then transfer to private sectors to operate and finally transfer back to the government which implies government takes most of the risks of the project. Combination of BOT, ROT and OT framework means a balanced right and obligation between two sides and keeps economic incentives for private sectors. Solely OT means private sectors are only taking operating risks during concession periods. This study surveys costs and revenues of two frameworks to evaluate the financial feasibility of the projects under two frameworks.

\section{DATA PRocessing AND PARAMETER SETting}

\section{A. Reconstruction Plans and Facilities of the Sugar Park}

The traditional sugar railway experience tour is the major activity for tourists in Sugar Railway Park which was the highlight of the park before the initiative of the project in 2018. The sugar railway which was operated by transferring sugar cane from cultivation land to sugar plants, and taking sugar farmers and workers during sugar production for the sugar company. Because many old facilities and buildings at the sugar plant have cultural heritage identity, the reconstruction plan of the heritage park focuses on reconstruction and reuse of old heritage architectures building (by ROT), and construct new buildings for additional services for tourists (by BOT). In the short term (for first 10 years) and medium term (for next 10 years), the Park plans to establish a youth creation plaza, the Sugar Railway Dynamic Reserve Park, a LOHAS park for accommodation, a central park, an agronomy market plaza and to encourage business groups of the sugar company to enter and be stationed in the Park. All the facilities and activities are followed by circular economy principles such as closed-loop of resources and sustainable development concept.

The youth creation plaza is designed for young people to 
operate creative shops, maker spaces, creative workshops, and extending functions of an old Tang-Fu Printing Institute which was established in 1954 and completely reserved an old movable type printing machine to a Tang-Fu Printing Creative Museum. The Sugar Railway Dynamic Reserve Park is designed for exhibitions and reservation of sugar culture and facilities in Taiwan, plans to curate special exhibitions for other themes, reserves the story and history of old sugar workers, and extended service for tourists of sugar railway and easier maintaining the old sugar railway which will link to other famous tourist attractions from Yanshui district to bring tourists into the Park by sugar railway extension. LOHAS accommodation park is designed for multifunctional usage not only for accommodation for youth and backpackers, over-night tourists, long stay service for the healthy senior citizen, long-term care service for the disabled citizen, but also provide leaning and doing exercises spaces and educational courses for local people and tourists. Agronomy market plaza is designed for operating farmers market or second-hand market, souvenir and famous ice lolly and provide catering services with local agricultural products. The central park is designed for providing landscape art, leisure and relax place, catering and café, and kinds of performance arts such as concert, a lantern festival, and street artists.

\section{B. Cost and Revenue of the plan}

The reconstruction costs of facilities of the Park in this study (total USD 205.49 million) are included:

Ref. [1] restoration and reuse costs of Tang-Fu Printing Creation Museum (USD 1.096 million),

Ref. [2] cost of Youth Creation Plaza (USD 0.05 million),

Ref. [3] costs of restoration of historic buildings within the Sugar Railway Dynamic Conservation Park (USD 21.62 million) including the cost of Exhibition and Education Park of Sugar Railway (USD 16 million) and restoration cost of old buildings (USD 5.62 million),

Ref. [4] restoration costs of old warehouses, facilities for business groups of Sugar Company (USD 21.96 million)

[5] costs related to LOHAS accommodation park (USD 156.76 million) including new architectures (USD 144.895 million)(new hotel, long-term care building, and learning and athlete space) and reconstruct old buildings (USD 11.87million),

Ref. [6] cost of central park (USD 2.21 million).

The operating and maintenance costs including salary (USD 0.278 million at first year, and increase $3 \%$ at every 3 years interval) and insurance costs (including labor insurance, health insurance, public liability insurance, and property insurance), operating cost of sugar railway (USD 0.4 million at first year and increase $1.3 \%$ according to average price inflation), operating cost for other facilities (USD 0.052 million at first year, and increase $1.3 \%$ according to average 3 -year price inflation), property insurance and lawyer and accountant service costs (USD 0.0189 million at first year), costs related to marketing, public relations, and the organization of various activities (USD 0.0433 million at first year), costs related to taxation, management, administration, design supervision, quality control, hygiene and safety facilities, services, general affairs, postage, fax, phone, and stationery (USD 0.05 million at first year), and cost of replacement/overhaul includes redecoration cost and landscape engineering cost (USD 0.784 million at first year with $5 \%$ and $10 \%$ increase for every 10 years interval for redecoration and landscape engineering costs respectively).

Revenues of the Sugar Railway Park in medium term were determined by business activities each year, including:

Ref. [1] BOT-type royalties and operating royalties (5\%) from most of the stores, shops, restaurants, and hotels (USD 1,190,000),

Ref. [2] sales revenues of admission charge, tickets, and tuition from sugar railway (USD 932,400), Tang-Fu Printing Museum (USD 84,460), exhibition hall (USD 147,000), learning and athlete course (old warehouse and garage) (USD 54,159),

Ref. [3] 15\% revenues from the cultural innovative stores (USD 138,320), maker spaces (USD 245,016), restaurants reconstructed (USD 139,104) from old red brick warehouses, offices, Japanese-style architectures, and old dormitory

Ref. [4] revenues from rents of all renting rooms, spaces, warehouses and stores (USD 4,618,660),

Ref. [5] revenues from accommodation of youth hostel, Japanese-style hotel, and superior hotel ( USD\$388,742) each year,

Ref. [6] 15\% revenues from long-term care center (new building) (USD 2,858,027) each year,

Ref. [7] sales revenues from Sugar Company's souvenirs and the tourist information office (USD 102,700),

Ref. [8] revenues from outdoor restaurants (USD 159,466) and food trucks (USD 155,102) and indoor restaurants (USD 245016) at central park, and

Ref. [9] Revenues from parking space (295 parking spaces, USD 270,000 per year).

\section{Financial analysis parameters}

Ref. [1] The base year is 2018. Construction for five years of the short term, 2018 to 2022 and three years for the medium term, 2033 to 2035 . Operating for 10 years from 2023 to 2032 of short-term and 2036 to 2045 of medium term.

Ref. [2] Duration of each contraction is 5 years.

Ref. [3] Price inflation is $1.3 \%$ annually (average price inflation from 2014 to 2016).

Ref. [4] Wage inflation is $1.71 \%$ in a 5-year interval (average wage inflation from 1997 to 2016).

Ref. [5] Due to the absence of financing requirements on behalf of the Sugar Company, the capital structure used in this project was $5.86 \%$ (for a combination of BOT $82.97 \%$, ROT $11.17 \%$ and OT $5.86 \%$ ) and $100 \%$ self-funded (for solely OT).

Ref. [6] Most Attractive Rate of Return (MARR)

Because of low operation risk of the Sugar Company which is a state-owned enterprise, the MARR equals to $3.5 \%$ was used as the main discount rate in the financial analysis. Sensitivity analysis was conducted for $5 \%$ discount rate level with regard to the future increase of interest rate.

Ref. [7] Occupancy rate

The occupancy rate for the Japanese-style and superior hotel are setting at $37 \%$ of average rate nearby, and $50.14 \%$ for the youth hostel.

Ref. [8] Ticket income and construction cost of the 
extension of Sugar Railway

Ticket fare is USD 3.33 for adult, half for children, and free for disabled people. Market shares of adult, children and disabled are estimated by historical data was set to $32 \%, 2 \%$, and $66 \%$. The construction cost of the extension of Sugar Railway to Yanshui district is ignored because the central government is responsible for it. This study considers the operating and maintenance cost of the extension of the railway.

Ref. [9] Equipment replacement and overhaul costs

Ref. [9.1] Replacement and redecorating cost

Redecorating cost has an expected duration of about 10 years, and $10 \%$ of initial replacement cost increase for one 10 -year interval.

Ref. [9.2] Overhaul cost

Overhaul cost has a lifetime of about 10 years, and $5 \%$ of initial overhaul cost increase for one 10-year interval.

Ref. [10] Royalty

Ref. [10.1] Fixed royalty

The youth hostel, Japanese-style and superior hotel which is managed by OT and BOT frameworks. From the date of the signing of the land and building lease contract, the site's operator shall pay a lump sum royalty (17\% of initial investment) of USD 1220.32 thousand annually (The youth hostel is USD 7.84 thousand, Japanese-style hotel is USD 22.48 thousand, and superior hotel is USD 1190 thousand) . The contract duration is five years, and every five years, the fixed royalty is raised by $5 \%$.

[10.2] Royalty for changes in operations

Set at $5 \%$ of the site operator's actual sales revenue (pre-tax) for each year.

\section{Initial Investment Cost}

The project's initial investment costs include reconstruction and reuse costs and new hotel construction cost are estimated to be USD 205.49 million (Table I). The extension of Sugar Railway to Yanshui district for short-term costs USD 1.56 thousand for $0.9 \mathrm{~km}$, and for medium-term costs USD 14.25 million for $8.2 \mathrm{~km}$ which are funding by the central government that is not included in OT framework for the Sugar Company, it will only operate and maintains the extension of the railway. The revenue of all facilities of the first year is USD 2.17 million in short-term and USD 10.73 million in medium term at the first year, and then adjust by royalty of 5-year contract, increase of visitors ( 0.31 million in short-term and 0.60 million in medium-term) and price inflation, which will be USD 2.44 million and USD 12.05 million.

TABLE I: TOTAL INITIAL INVESTMENT COST AND REVENUE FOR RESTORATION AND REUSE OF SUGAR RAILWAY RESERVATION PARK

\begin{tabular}{|c|c|c|c|}
\hline \multicolumn{4}{|c|}{ HERITAGE } \\
\hline Facilities & $\begin{array}{c}\text { Short-term } \\
\text { initial cost } \\
\text { (Million } \\
\text { USD) }\end{array}$ & $\begin{array}{l}\text { Medium-ter } \\
\text { m initial cost } \\
\text { (M USD) }\end{array}$ & $\begin{array}{c}\text { Total } \\
\text { initial cost } \\
\text { (M USD) }\end{array}$ \\
\hline Youth Creation Plaza & 2.93 & 0.00 & 2.93 \\
\hline $\begin{array}{l}\text { Sugar Railway Dynamic } \\
\text { Reservation Park }\end{array}$ & 5.62 & 16.00 & 21.62 \\
\hline $\begin{array}{l}\text { Bussiness Groups of Sugar } \\
\text { Company }\end{array}$ & 1.07 & 16.05 & 17.12 \\
\hline Agronomy Market Square & 4.75 & 0.08 & 4.83 \\
\hline LOHAS Accommoation Park & 0.55 & 156.21 & 156.77 \\
\hline Central Park & 0.00 & 2.21 & 2.21 \\
\hline
\end{tabular}

\begin{tabular}{|c|c|c|}
\hline Total cost & 14.93 & 205.49 \\
\hline Facilities & $\begin{array}{c}\text { Short-term revenue } \\
\text { (M USD) } \\
\text { (first year) } \\
\end{array}$ & $\begin{array}{c}\text { Medium-term } \\
\text { revenue (M USD) } \\
\text { (first year) }\end{array}$ \\
\hline Youth Creation Plaza & 0.25 & 0.35 \\
\hline $\begin{array}{l}\text { Sugar Railway Dynamic } \\
\text { Reservation Park }\end{array}$ & 0.23 & 0.56 \\
\hline $\begin{array}{l}\text { Bussiness Groups of Sugar } \\
\text { Company }\end{array}$ & 0.54 & 1.79 \\
\hline Agronomy Market Square & 0.58 & 1.16 \\
\hline LOHAS Accommodation Park & 0.02 & 5.11 \\
\hline Central Park & 0 & 0.56 \\
\hline Sugar Railway & 0.48 & 0.93 \\
\hline Parking Space & 0.07 & 0.27 \\
\hline Total Revenue & 2.17 & 10.73 \\
\hline
\end{tabular}

\section{E. Total Expenditure for Restoration and Reuse}

Table II reveals detail initial investment cost composition from Table I and describe the BOT/ROT/OT framework of combination scenario. The cost of BOT, ROT and OT are USD 170.495 million, USD 22.96 million and USD 12.03 million, respectively, and USD 250.49 million totally.

TABLE II: TOTAL INITIAL INVESTMENT FOR RESTORATION AND REUSE OF THE PARK (UNIT: MILLION USD)

\begin{tabular}{|c|c|c|c|c|c|c|}
\hline $\begin{array}{c}\text { Sugar } \\
\text { Company }\end{array}$ & Facilities & Frameworks & Sub-cost & $\begin{array}{c}\text { Short } \\
\text {-term } \\
\text { initial } \\
\text { cost }\end{array}$ & $\begin{array}{c}\text { Medium } \\
\text {-term } \\
\text { initial } \\
\text { cost }\end{array}$ & $\begin{array}{c}\text { Total } \\
\text { initial } \\
\text { investme } \\
\text { nt cost }\end{array}$ \\
\hline \multirow{3}{*}{$\begin{array}{c}\text { Youth } \\
\text { Creation } \\
\text { Plaza }\end{array}$} & $\begin{array}{l}\text { Tang-Fu Printing } \\
\text { Museum }\end{array}$ & ROT & 1.10 & \multirow{3}{*}{2.93} & & \multirow{3}{*}{2.93} \\
\hline & Youth Creation Stores & ROT & 0.73 & & & \\
\hline & $\begin{array}{c}\text { Youth Creation } \\
\text { Workshop and } \\
\text { Courses }\end{array}$ & ROT & 1.11 & & & \\
\hline \multirow{6}{*}{$\begin{array}{c}\text { Sugar } \\
\text { Railway } \\
\text { Dynamic } \\
\text { Reservati } \\
\text { on Park }\end{array}$} & Visitors Center & ROT & 0.51 & \multirow{6}{*}{5.62} & \multirow{6}{*}{16.00} & \multirow{6}{*}{21.62} \\
\hline & Exhibition Spaces & ROT & 2.43 & & & \\
\hline & Catering Spaces & ROT & 0.10 & & & \\
\hline & $\begin{array}{c}\text { Sugar Railway } \\
\text { Maintenance Space }\end{array}$ & ROT & 1.27 & & & \\
\hline & $\begin{array}{l}\text { Collection Space } \\
\text { Exhibition and }\end{array}$ & ROT & 1.31 & & & \\
\hline & $\begin{array}{l}\text { Education Space of } \\
\text { Sugar Railway }\end{array}$ & BOT & 16.00 & & & \\
\hline $\begin{array}{l}\text { Business } \\
\text { Groups } \\
\text { of Sugar } \\
\text { Company }\end{array}$ & $\begin{array}{l}\text { Business Group of } \\
\text { Sugar Company }\end{array}$ & ROT $、$ BOT & 17.12 & 1.07 & 16.05 & 17.12 \\
\hline \multirow{7}{*}{$\begin{array}{c}\text { Agronom } \\
\text { y Market } \\
\text { Square }\end{array}$} & Catering Spaces & ROT & 0.10 & \multirow{7}{*}{4.75} & \multirow{7}{*}{0.08} & \multirow{7}{*}{4.83} \\
\hline & $\begin{array}{l}\text { Super Market of } \\
\text { Sugar Company }\end{array}$ & ROT & 0.35 & & & \\
\hline & Main Hall & ROT & 0.90 & & & \\
\hline & Catering Spaces & OT & 0.46 & & & \\
\hline & Retailing Space & ROT & 0.77 & & & \\
\hline & Administration Office & ROT & 2.17 & & & \\
\hline & Catering Spaces & OT & 0.08 & & & \\
\hline \multirow{7}{*}{$\begin{array}{l}\text { LOHAS } \\
\text { Accomm } \\
\text { odation } \\
\text { Park }\end{array}$} & Youth Hostel & ROT & 0.55 & \multirow{7}{*}{0.55} & \multirow{7}{*}{156.21} & \multirow{7}{*}{156.77} \\
\hline & Japanese-style Hotel & OT & 1.59 & & & \\
\hline & Catering Spaces & OT & 1.35 & & & \\
\hline & $\begin{array}{l}\text { Health and Athlete } \\
\text { Space }\end{array}$ & ROT $、$ OT & 3.83 & & & \\
\hline & Indoor Activity Space & OT & 5.55 & & & \\
\hline & New Superior Hotel & BOT & 84.00 & & & \\
\hline & $\begin{array}{c}\text { Long-term Care } \\
\text { Center }\end{array}$ & BOT & 59.90 & & & \\
\hline \multirow[t]{2}{*}{$\begin{array}{l}\text { Central } \\
\text { Park } \\
\end{array}$} & Catering Spaces & OT & 2.21 & & 2.21 & 2.21 \\
\hline & Grand Total & & 205.49 & 14.93 & 0.00 & 205.49 \\
\hline
\end{tabular}

F. Operating and Maintenance Costs

The total operating costs and expenditures for operating 
facilities of short-term and medium-term at first year as list above will be USD 0.98 million and USD 2.87 million, then adjusting by price inflation and wage inflation to the end of operation period in short-term (10 years) and medium-term (10 years) which will be USD 1.07 million and USD 3.97 million. All O\&M cost is smaller than revenue at all-time which implies the project will not bankrupt during operation periods.

\section{G. Scenario Design}

This study evaluates the Park's financial feasibility using expected cash inflow and outflow with the time value of money and calculating financial indicators. This study performs three scenarios including a combination of BOT, ROT and OT frameworks in the short-term and medium-term which implies most of the project cost and operating risks are responsible for concession companies, and all cost and operation by the Sugar Company itself which is so-called the solely OT scenario. The short-term scenario performs from 2018 to 2032 which combines 5-year restoration and reconstruction periods and 10-year operating period, the medium-term scenario performs from 2018 to 2045 which combines short-term period, 3 year construction period and 10 year operation period. The interest rate (discount rate) was set at $3.5 \%$, and risk analysis was used for risk assessment by setting at $5 \%$.

\section{FinANCIAL CALCUlation Results AND ANALysis}

A. Short-term BOT/ROT/OT Scenario Analysis: Financial Feasibility Analysis Assuming an Interest Rate of $3.5 \%$

In Table III, the Park's NPV in short term is USD7.24 million, of which the present values of revenues and costs are USD 17.86 and USD 10.62 million, respectively, revealing that the project will generate positive net cash inflow (also implies actual purchasing power) for the Sugar Company in 2018 (base year). The results imply that the project of the Park is worth investing in for the Sugar Company and the concession companies.

The project's SLR is $463.81 \%$ which implies that it can fully cover initial investment of the project, it also implies that to invest and operate the Park project will be quite safe with low risks. The project's IRR is $30.13 \%$, which is much higher than the MARR of $3.5 \%$, implying a $90 \%$ increase in additional profits. ERR is slightly lower at $16.05 \%$ also much higher than MARR; therefore, the project's return on investment is sufficiently attractive for the Sugar Company and concession companies. Equity IRR and equity ERR are consistent with original IRR and ERR because the Park is major funding by the outsourcing firms and government, the Sugar Company almost need not an investment and will not take an external loan or debt in the project.

The project's $\mathrm{B} / \mathrm{C}$ ratio is 1.68 which describes that the present value of the project's revenue is higher than the present value of cost by $68.1 \%$. This is also a positive indicator for the Sugar Company and operating firms. The project's PI is 4.64 (similar with SLR), implying that each USD1 in initial investment made by the project's shareholders is able to generate USD 4.64 in revenue, implies the project will get the initial investment back for its shareholders.

Regarding payback period, the Park will generate profits in 2024, 2 years after it commences operations in 2023. The project's payback period in first 10-year operation is short and seems very attractive, the Park also carries ideal purposes such as the development of the circular economy, long-term care demand for local people, communicate and cooperate with local people, and bring lifetime learning and healthy life to citizens.

TABLE III: FINANCIAL FEASIBILITY ANALYSIS FOR SHORT TERM OPERATION AT $3.5 \%$ DisCOUNT RATE (UNIT: MILLION USD)

\begin{tabular}{cc} 
AT 3.5\% DISCOUNT RATE (UNIT: MILLION USD) \\
\hline Interest rate & Discount rate 3.5\% \\
\hline NPV & 7.24 \\
IRR & $30.13 \%$ \\
ERR & $16.05 \%$ \\
Equity IRR & $30.13 \%$ \\
Equity ERR & $16.05 \%$ \\
PV Revenue & 17.86 \\
PV Cost & 10.62 \\
B/C & 1.68 \\
Profit Index & 4.64 \\
& The second year after the operation \\
Discount Payback period & at 2023 \\
Self-liquidation ratio SLR & $463.81 \%$ \\
Base year & 2018 \\
\hline \hline
\end{tabular}

\section{B. Medium-term BOT/ROT/OT Scenario Analysis:}

Financial Feasibility Analysis Assuming an Interest Rate of $3.5 \%$ and Risk Analysis at an Interest Rate of 5\%

In Table IV, the Park's NPV in the medium term is USD 43.99 million, of which the present values of revenues and costs are USD 74.73 and USD 30.75 million at $3.5 \%$, respectively, revealing that the project will also generate positive net cash inflow for Sugar Company. The results also imply that the project of the Park is worth investing in for the Sugar Company and the concession companies in the medium term (from 2018 to 2046) and taking much higher profit than short-term scenario.

The project's SLR is $1800.65 \%$ which implies that it can cover initial investment of the project, it also implies that the project will generate high profit and be much safer with lower risks than short-term scenario. The project's IRR/Equity IRR and ERR/Equity ERR are $33.07 \%$ and $15.45 \%$ which are higher than short-term scenario. The project's return on investment is sufficiently attractive for the Sugar Company, government, and concession companies.

The project's benefit-cost ratio is 2.43 which describes that the present value of the project's revenue is higher than the present value of cost by $143 \%$ and two times higher than short-term scenario. The project's PI is 18.01 which implies that each USD 1 in initial investment made by the project's shareholders is able to generate USD18.01 in revenue, implies the project will not only get the initial investment back but also very profitable for the Sugar Company.

Regarding the medium-term payback period, the Park will generate profits in 2036, the first year after it commences operations in 2036.

TABLE IV: FINANCIAL FEASIBILITY ANALYSIS FOR MEDIUM TERM OPERATION AT 3.5\% AND 5\% DISCOUNT RATE (UNIT: MILLION USD)

\begin{tabular}{ccc}
\hline \hline Interest rate & Discount rate $3.5 \%$ & Discount rate $5 \%$ \\
\hline NPV & 43.99 & 32.80
\end{tabular}




\begin{tabular}{ccr} 
IRR & $33.07 \%$ & $33.07 \%$ \\
ERR & $15.45 \%$ & $16.27 \%$ \\
PW Revenue & 74.73 & 57.33 \\
PW Cost & 30.75 & 24.53 \\
B/C & 2.43 & 2.34 \\
Profit Index & 18.00 & 14.58 \\
Discount Payback & The first year after the & The first year after \\
period & operation & the operation \\
Self-liquidation & at 2036 & at 2036 \\
ratio & $1800.65 \%$ & $1457.67 \%$ \\
\hline \hline
\end{tabular}

For the risk analysis, in Table IV, indicators show that a 5\% interest rate can generate a lower NPV, B/C ratio, IRR and SLR than $3.5 \%$ scenario which the Park would generate lower profit. Only $1.5 \%$ (3.5\% to $5 \%$ ) increase of interest rate will generate $25.47 \%$ decrease of NPV, and SLR will decrease nearly $350 \%$ which implies the financial structure of the Park is interest-sensitive; hence, the Sugar Company has to monitor the fluctuation of market interest rates and the credit rating of the Company to maintain the financial and operational stability of the Park, and keep the Park's goals to attract flow of local and global visitors continues.

\section{Short-term and Medium-term Solely OT Scenario Analysis: Financial Feasibility Analysis Assuming an Interest Rate of $3.5 \%$}

In Table V, the Park's NPV in short and medium term are USD -9.66 million and USD -80.59 million respectively, describing that the project will not generate positive net cash inflow for the Sugar Company during the operation of the Park. All financial indicators reveal same results, such as SLR are lower than $40 \%$ which implies all initial investment cost will get back only $40 \%$ in future, the rate of return are all negative, $\mathrm{B} / \mathrm{C}$ ratio is less than one implies a present value of cost is greater than revenue. Regarding the payback period, the scenario of two time periods will never get back the initial investment of the project at the end of the year 2046.

TABLE V: FINANCIAL FEASIBILITY ANALYSIS FOR SHORT TERM AND MEDIUM TERM OPERATION FOR OT SCENARIO AT 3.5\% DisCOUNT RATE (UNIT: MILLION USD)

\begin{tabular}{lcc}
\hline \hline \multicolumn{1}{c}{ Interest rate } & Short term & Medium term \\
\hline NPV & -9.66 & -80.59 \\
IRR & $-8.18 \%$ & $-10.75 \%$ \\
PW Revenue & 17.86 & 74.31 \\
PW Cost & 27.52 & 155.32 \\
B/C & 0.65 & 0.48 \\
Profit Index & 0.40 & 0.35
\end{tabular}

Discount Payback period Never break-even at Never break-even a $\begin{array}{ccc} & \text { the end of the project at } 2046 \text { the end of the project } \\ \text { Self-liquidation ratio } & 39.70 \% & 35.35 \%\end{array}$

\section{Discussion}

First of all, the BOT/ROT/OT framework will generate enough financial stability for operating the cultural heritage site and are beneficial to both public and private sectors. Most of the operating risks are taken by concession companies which implies the project should generate enough net cash inflow to share with both sides. If not, the public sectors may prevent loss because it takes fixed royalty and rent from concession companies, but the private sectors will suffer a great loss. The OT scenario implies all cost are paid by the public sector, revenue comes from receiving royalty and rent which are relatively small part of the initial investment cost expenditure that the public sectors may not make a profit in the project. To balance risks between public and private sectors is the most issue during the project.

Cultural heritage needs continuously funding and management to support reconstruct and refurbish the historical buildings and facilities. Self-sufficient finance ability of the heritage site depends on a workable business model to generate enough and continuous cash inflow to support operating and maintaining the cultural heritage. To conserve private-owned cultural heritages needs care in financing stability, heritage management, monitoring, and professional reservation techniques. Not only the conservation management of the heritage need to be considered, the original objectives of the reconstruction and reuse of the heritage also needed to keep on the track in the long-term. Then providing an economic incentive to tourists to make them be regulars and fans of the heritage. Promoting the sites to keep visitor attractions of the heritage to generate enough customers to the sites to generate net cash inflow.

This study only considered to medium term scenario because of a long-term plan will depend on the development situation of the medium-term period. As unpublished test results, the scenario of a combination of BOT/ROT/OT will be profitable in the long-term period, and profit of solely OT scenario may turn to positive after 20 years because the O\&M cost is relatively lower than the cost of constructing new architectures of the medium term in the future.

The benefit generated by the Park not only consider financial value but also invisible benefit and cost of the project. The social benefit such as preserving the precious cultural heritage of sugar industry and intangible sugar culture in Taiwan, implementing circular economy, support long-term care and healthy life, communicate local community and attract young people back to the countryside, and reserve beautiful green land and environment protection. These invisible social value also need to be estimated and counted as the total social value of the project.

\section{CONCLUSION}

This study conducts a valuable financial evaluation for restoration and reuse of Sugar Railway Park and compared effects of the combination of BOT/ROT/OT and solely OT concession frameworks to a reuse project. The BOT/ROT/OT frameworks of this project will be financially feasible at $3.5 \%$ and $5 \%$ discount rate in short term and medium term, but not for OT concession scenario.

Not only financial feasibility, the extension of Sugar Railway Park conforms to value of experience tourism, restored and reused Sugar Plant and Railway cultural heritage, long-term care, healthy LOHAS life, circular economy and sustainable development, and localized concept with high social value in a historical city Tainan.

\section{REFERENCES}

[1] H. W. Lin, "Sweetened imposition: Re-examining the dilemma of the adaptive reuse of former sugar factory sites as cultural creative parks in 
Taiwan," International Journal of Cultural and Creative Industries, vol. 2, no. 2, pp. 68-83, 2015.

[2] H. W. Lin, "On colonial industries: The remnants of bygone sugar factories in Taiwan," International Journal of Social Science and Humanity, vol. 5, no. 11, pp. 931-936, 2015.

[3] D. H. Lee, H. W. Lin, and M. F. Hsu, "Analysis of the financial feasibility of reusing the former plastic manufacturing heritage site in Taiwan," International Journal of Social Science and Humanity, vol. 7, no. 8, pp.591-598, 2017.

[4] World Bank. PPP Arrangements / Types of Public-Private Partnership Agreements. [Online]. Available: https://ppp.worldbank.org/public-private-partnership/agreements

[5] J. Delmon, "Understanding options for public-private partnerships in infrastructure sorting out the forest from the trees: BOT, DBFO, DCMF, concession, lease...," Policy Research Working Paper 5173, The World Bank. [Online]. Available: https://openknowledge.worldbank.org/handle/10986/19947

[6] World Bank. Regional development in the Copan valley project appraisal document. [Online]. Available: http://documents.worldbank.org/curated/en/824231468771069309/H onduras-Regional-Development-in-the-Copan-Valley-Project

[7] S. Johnston, J. Morison, R. Stringer, P. Mickan, M. Salver, G. Sarre and J. Tagliaferri, "UNESCO world heritage site listing for the mount lofty ranges agrarian landscape. [Online]. Available: http://www.mountloftyranges.org/about.html

[8] E. Kałużyńska, A. Dowd, and S. Dickinson, "An investigation into viability of restoration and reuse of a listed property: A case study of project Hala located in warsaw. [Online]. Available: shura.shu.ac.uk/7579/1/kaluzynska,_dowd_and_dickinson.pdf.

[9] Department of arts, heritage, and the gaeltacht. Cost-benefit analysis of the national archives warehouse development plan. [Online]. Available: https://www.chg.gov.ie/app/uploads/2016/11/na_cba_final.pdf

[10] A. Baez and L. C. Herrero, "Using contingent valuation and cost-benefit analysis to design a policy for restoring cultural heritage," Journal of Cultural Heritage vol. 13, pp. 235-245, 2012.

[11] R. Morimoto and C. Hope, "Applying a CBA model to the three gorges project in China. [Online]. Available: http://citeseerx.ist.psu.edu/viewdoc/download?doi=10.1.1.317.9403\& rep=rep $1 \&$ type $=$ pdf

[12] Common Wealth. Market and financial feasibility study for the old post office Dawson creek, BC. Prepared by Commonwealth Historic Resource Management Limited AMS Planning \& Research Inc. [Online]. Available: http://www.dawsoncreek.ca/wordpress/wp-content/uploads/2011/10/ MarketandFeasibilityStudy-InterimReportNo1 forwebsite.pdf

[13] M. Sesotyaningtyas and A. Manaf, "Analysis of sustainable tourism village development at Kutoharjo village, kendal regency of central Java," Procedia - Social and Behavioral Sciences, vol. 184, pp. 273-280, 2015

[14] B. Kayahan, "Cost-benefit analysis of UNESCO world heritage site designation in nova scotia," Review of Economic Analysis, vol. 4, pp. 247-273, 2012

[15] G. J. Thuesen and W. G. Sullivan, "Engineering Economy a Historical Perspective," Paper presented at 1999 Annual Conference, Charlotte, North Carolina.

[16] L. Blank and A. Tarquin, Engineering Economy, $7^{\text {th }}$ ed., McGraw Hill: New York, 2012.

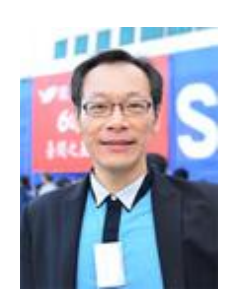

Lee Duu-Hwa earned his Ph.D. in Agricultural Economics (2001) at National Taiwan University in Taiwan. Dr. Lee is a Professor at Institute of Applied Economics at National Taiwan Ocean University. Dr. Lee's expertise includes agricultural economics, new energy evaluation, environmental economics, computable general equilibrium analysis, input-output analysis, ocean economy, leisure and tourism economics, policy evaluation and free trade analysis. Dr. Lee was elected as a supervisor of Taiwan Association of Input-Output Studies in 2016.

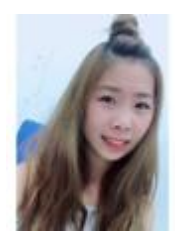

Lin Ching-Ching was born in Keelung, Taiwan on 2th February in 1994. She earned her bachelor degree in economics (2016) at Aletheia University in Taiwan. She is a graduate student of Institute of Applied Economics at Nation Taiwan Ocean University now.

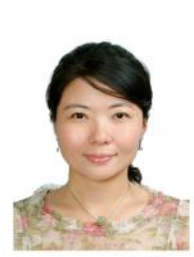

Hui-Wen Lin is an associate Professor at the Institute of Creative Industries design in National Cheng Kung University in Taiwan. She is also the Associate Librarian in the university library.

Her research outcomes include the paper published in the International Journal of Heritage Studies was also published by Taylor \& Francis in 2015, under title of "The selected representation of contested prison history: memorial exhibitions and tourist experiences. Dr. Lin has been a member of the International Council on Monuments and Sites (ICOMOS) since 2013. She has also been elected as Board member of the Foundation of Historic City Conservation and Regeneration in 2012.

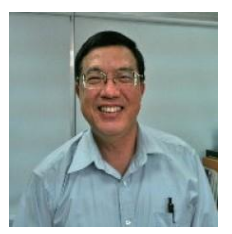

Min-Fu Hsu earned his Ph.D. in Architecture (1986) at University of Edinburgh in UK, her M.A. (1979) and B.A. (hons) (1976), both in Architecture, from National Cheng Kung University in Taiwan. Dr. Hsu is the Tenure and Distinguished Professor at the Department of Architecture in National Cheng Kung University, as well as the Chairman of Society of Architectural Historian of Taiwan- NCKU Research \& Development Foundation and the Chairman of Building Performance Assessment Centre. 